San Jose State University

SJSU ScholarWorks

Master's Theses

Master's Theses and Graduate Research

Spring 2020

\title{
The Mediating Role of Work Engagement on the Relationship Between Perceived Supervisor Support and Turnover Intention
}

Addison Yeosock

San Jose State University

Follow this and additional works at: https://scholarworks.sjsu.edu/etd_theses

\section{Recommended Citation}

Yeosock, Addison, "The Mediating Role of Work Engagement on the Relationship Between Perceived Supervisor Support and Turnover Intention" (2020). Master's Theses. 5117.

DOI: https://doi.org/10.31979/etd.qgpu-m2pf

https://scholarworks.sjsu.edu/etd_theses/5117

This Thesis is brought to you for free and open access by the Master's Theses and Graduate Research at SJSU ScholarWorks. It has been accepted for inclusion in Master's Theses by an authorized administrator of SJSU ScholarWorks. For more information, please contact scholarworks@sjsu.edu. 


\author{
A Thesis \\ Presented to \\ The Faculty of the Department of Psychology \\ San José State University
}

In Partial Fulfillment

of the Requirements for the Degree

Master of Science

by

Addison Yeosock

May 2020 
(C) 2020

Addison Yeosock

ALL RIGHTS RESERVED 
The Designated Thesis Committee Approves the Thesis Titled

THE MEDIATING ROLE OF WORK ENGAGEMENT ON THE RELATIONSHIP BETWEEN PERCEIVED SUPERVISOR SUPPORT AND TURNOVER INTENTION

\author{
by \\ Addison Yeosock \\ APPROVED FOR THE DEPARTMENT OF PSYCHOLOGY \\ SAN JOSÉ STATE UNIVERSITY
}

May 2020

Dr. Megumi Hosoda

Dr. Howard Tokunaga

Dr. B. Lynn Ware
Department of Psychology

Department of Psychology

Integral Talent Systems, Inc. 


\section{ABSTRACT \\ THE MEDIATING ROLE OF WORK ENGAGEMENT ON THE RELATIONSHIP BETWEEN PERCEIVED SUPERVISOR SUPPORT AND TURNOVER INTENTION

\author{
by Addison Yeosock
}

The purpose of the current study was to examine the mediating role of work engagement on the relationship between perceived supervisor support and turnover intention using the Jobs Demands-Resources (JD-R) model and the motivational processes of engagement as the theoretical framework. A total of 954 employees of a healthcare organization participated in an online survey. Results showed that work engagement partially mediated the relationship between perceived supervisor support and turnover intention. Perceived supervisor support was negatively related to turnover intention directly and indirectly through work engagement. Based on these findings, organizations should focus on strategies of increasing the job resource of perceived supervisor support in order to motivate employees to be more engaged, which is likely to reduce the likelihood that they will leave the organization. 


\section{ACKNOWLEDGMENTS}

I would like to sincerely thank my thesis chair, Dr. Megumi Hosoda, for supporting me throughout this thesis process. The dedication to your students is beyond measure, and I appreciate all you do to ensure our success. I want to thank my second reader, Dr. Howard Tokunaga, for his guidance and keen eye to detail. I want to also thank my third reader, Dr. B. Lynn Ware, for being such an excellent mentor and leader. To my cohort, we did it! I could not have asked for a better group to share this experience with.

I want to dedicate this thesis to my family. To my dad, I could never express the amount of gratitude I have for you. I am forever indebted to you. To my mom, I am immensely appreciative of your love, support, and positivity. To my Grams, thank you for being such an inspiration and for being my number one fan. To my late Pops, thank you for always being the guiding light that got me to where I stand today. To the rest of my family, I am beyond grateful for your support and encouragement. And last but not least, I want to thank Andrew for his unwavering love and support. I love you all so much and could not have done this without you!

The journey leading up to this moment was nothing short of beautiful, and I wouldn't trade it for anything in the world. So much has happened to lead up to this moment and I could not be more grateful and in awe of the outcome. Character is not defined by what happens to you, but by how your respond. This is only the beginning! 


\section{TABLE OF CONTENTS}

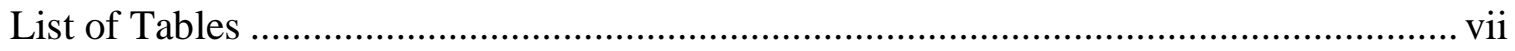

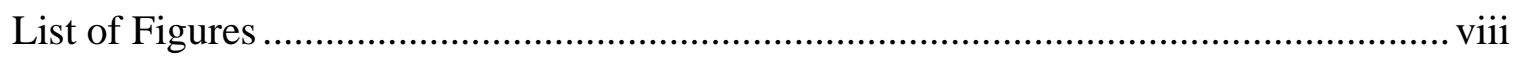

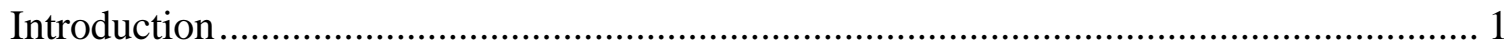

Definition of and Predictors of Turnover Intention ..................................................... 3

Social Exchange Theory …………………………….................................... 5

Job Demands-Resources (JD-R) Model............................................................ 7

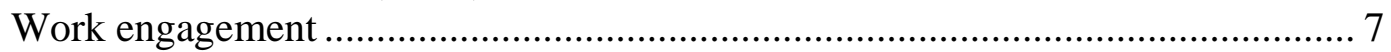

Predictors of work engagement ................................................................... 9

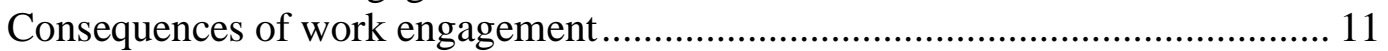

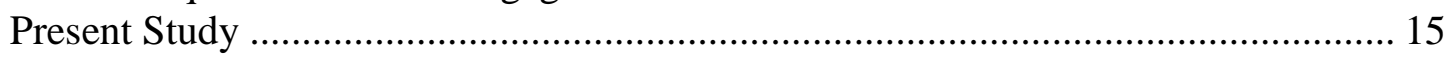

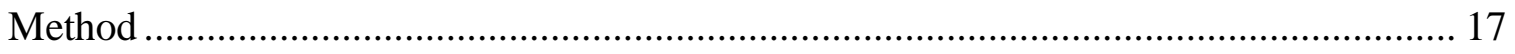

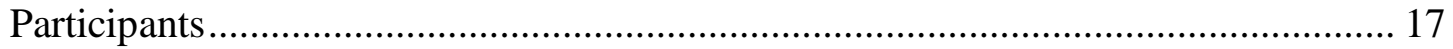

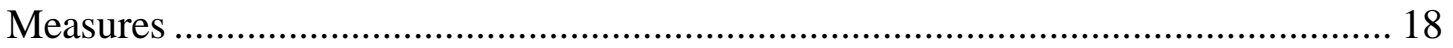

Perceived supervisor support ......................................................................... 18

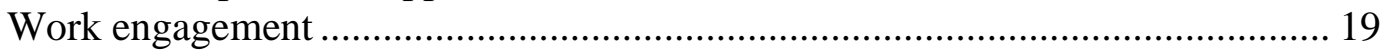

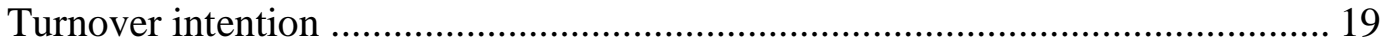

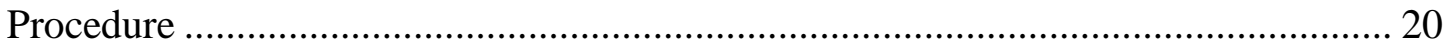

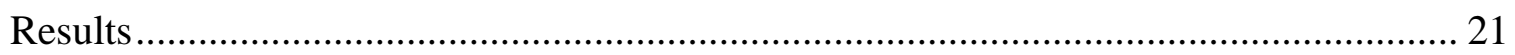

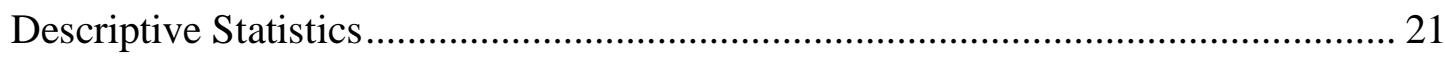

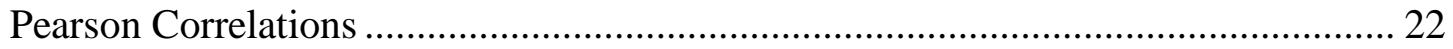

Test of Hypothesis ............................................................................................ 22

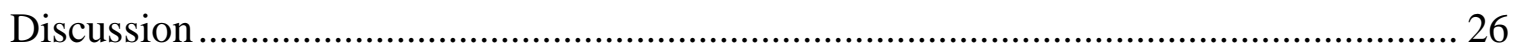

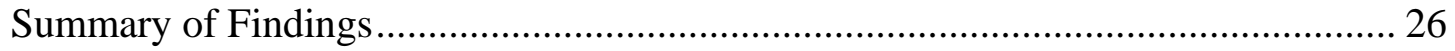

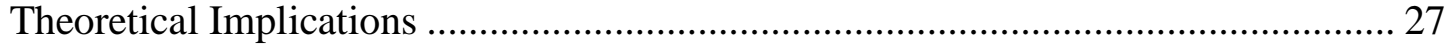

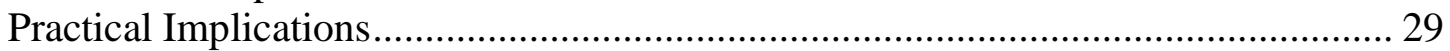

Strengths and Weaknesses of the Present Study, and Future Directions ..................... 31

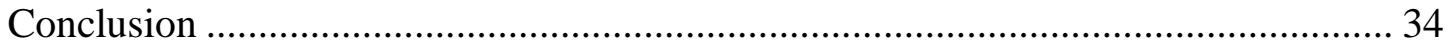

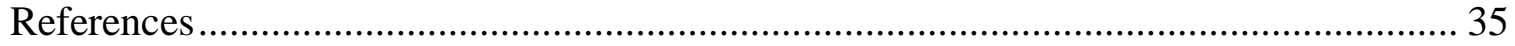

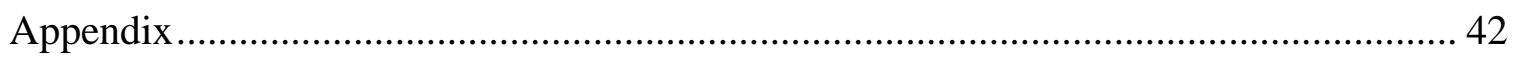

Demographic Questionnaire ………………………...................................... 42

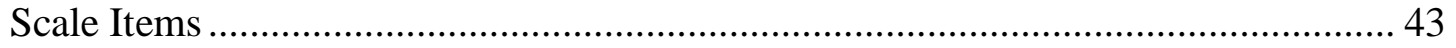




\section{List of Tables}

Table 1. Demographic Characteristics of Participants................................................18

Table 2. Descriptive Statistics and Pearson Correlations of Variables............................21

Table 3. The Results of the Relationship Between Perceived Supervisor Support (PSS) and Turnover Intention (TI) as Mediated by

Work Engagement............................................................................24 


\section{List of Figures}

Figure 1. Work engagement as a mediator of the relationship between perceived supervisor support and turnover intention.................................15

Figure 2. A simple mediation model with work engagement as the proposed mediator of the relationship between perceived supervisor support and turnover tntention.... 


\section{Introduction}

Turnover is one of the major concerns for organizations. For example, employee turnover costs organizations $90 \%$ to $200 \%$ of an employee's annual salary (Cascio, 2006). Such costs include severance pay, administrative costs, and costs associated with recruiting, hiring, onboarding, and training new employees. Not only are there costs associated with employee turnover, but there are other performance indicators that are impacted (Brown \& Medoff, 1978; Tziner \& Birati, 1996). For example, customer outcomes are negatively impacted, such as customer satisfaction, wait times, and service quality (Hausknecht \& Trevor, 2011). Turnover also disrupts established organizational systems by making coordination efforts and processes among team members harder due to a vacancy of an established role in the organization (Staw, 1980). Additionally, organizations lose the knowledge, skills, and abilities of employees when they leave the organization. Because turnover is costly to organizations, researchers have paid considerable attention to predictors of turnover.

Research has identified numerous predictors of turnover, including organizational commitment, job satisfaction, autonomy, tenure, and social support (Chang, Wang, \& Huang, 2013). However, one of the strongest predictors of turnover is turnover intention (Allen, Bryan, \& Vardaman, 2010). Turnover intention is the extent to which an employee intends to leave his or her organization (Ma \& Trigo, 2008). One of the most commonly found predictors of turnover intention is perceived supervisor support (Karatepe, 2014; Kim \& Jogaratnam, 2010; Nichols, Swanberg, \& Bright, 2016). Perceived supervisor support is defined as the degree to which supervisors value their 
employees' contributions and care about their well-being (Eisenberger, Stinglhamber, Vandenberghe, Sucharski, \& Rhoades, 2002; Kottke \& Sharafinski; 1988). An employee's relationship with his or her supervisor plays a critical role in the employee's intention to leave the organization (Allen, Bryant, \& Vardaman, 2010).

Although perceived supervisor support has consistently been shown to be related to reduced turnover intention, not much is known about the mechanisms of this relationship. However, when researchers (e.g., Nichols et al., 2016; Shuck, Twyford, Reio, \& Shuck, 2014) have examined potential mechanism underlying the relationship between perceived supervisor support and turnover intention, they have often used social exchange theory (Blau, 1964). This theory states that the mechanism of the relationship between perceived supervisor support and turnover intentions is a norm of reciprocity or felt obligations. However, the present study argues that motivation might also be an explanatory mechanism for the relationship between perceived supervisor support and turnover intention. More specifically, the present study proposes that work engagement acts as a mediator of the relationship between perceived supervisor support and turnover intention. Work engagement is defined as employees' harnessing of their selves to their work roles, as they express themselves physically, cognitively, emotionally, and mentally, and is a motivational construct (Kahn, 1990).

Using the job demands-resources (JD-R) model (Schaufeli \& Bakker, 2004), which states that job resources lead to a motivational state of engagement, which in turn is related to positive outcomes, the present study proposes that perceived supervisor support 
acts as a resource and is positively related to work engagement, which in turn is negatively related to turnover intention.

The following sections provide a definition of turnover intention, followed by a review of the literature on predictors of turnover intention. Next, I describe social exchange theory and review findings on mediators of the relationship between antecedents and outcomes using this theory, and then introduce the JD-R model theoretical framework and its findings, and the research hypothesis tested in this study.

\section{Definition of and Predictors of Turnover Intention}

As mentioned earlier, the study of turnover intention is important because the literature has identified turnover intention to be one of the strongest predictors of actual turnover (Allen, Bryant, \& Vardaman, 2010; Heavey, Holwerda, \& Hausknecht, 2013; Mobley, Horner, \& Hollingsworth, 1978; Tett \& Meyer, 1993). Turnover intention is defined as an employee's "conscious and deliberate willfulness to leave the organization" (Tett \& Meyer, 1993, p. 262). Due to turnover intention being the strongest predictor of turnover, researchers have paid a considerable amount of attention to identify predictors of turnover intentions. Examples of antecedents of turnover intentions include job satisfaction, affective organizational commitment, and perceived supervisor support (Freund, 2005; Gordon, Tang, Day, \& Adler, 2019; Karatepe, 2014; Kim \& Kao, 2014; Nichols et al., 2016).

Job satisfaction, defined as the overall evaluative judgments one has about one's job (Weiss, 2002), has been consistently shown to be negatively related to turnover intention (Chang et al., 2013; Feyerabend, Herd, \& Choi, 2018; Freund, 2005). In a meta-analysis 
conducted by Kim and Kao (2014), they found job satisfaction to be one of the strongest predictors of turnover intention. These findings indicate that the more employees are satisfied with their job, the less likely they are to intend to leave the organization.

Affective organizational commitment, or an employee's emotional attachment and involvement in their organization (Allen \& Meyer, 1996; Mowday, Steers, \& Porter, 1979), has also been shown to be negatively related to turnover intention. Freund (2005) found a negative relationship between affective organizational commitment and turnover intention. These findings indicate that the more employees are emotionally attached and committed to their organization, the less likely they are to develop an intention to leave their organization.

Another widely studied predictor of turnover intention is perceived supervisor support. Perceived supervisor support is defined as employees' perceptions of the extent to which a supervisor values their contributions and cares about their overall well-being (Kottke \& Sharafinski, 1988). Supervisors who engage in supportive practices inform their subordinates of decision-making, communicate organizational information, provide them with performance feedback, and encourage their autonomy and development (Karatepe \& Kaviti, 2016).

Ample research has shown a significant and negative relationship between perceived supervisor support and turnover intention (e.g., Gordon et al., 2019; Kim \& Kao, 2014; Nichols et al., 2016). For example, Newman, Thanacoody, and Hui (2012) studied the relationship between perceived supervisor support and turnover intentions in a sample of 1,000 Chinese employees from five multinational organizations in the service sector. The 
researchers found perceived supervisor support was significantly and negatively related to turnover intentions. Maertz, Griffeth, Campbell, and Allen (2007) employed a sample of 225 social workers to investigate the relationship between perceived supervisor support and turnover intention. Results showed that perceived supervisor support was significantly and negatively related to turnover intention. These findings show that employees who believed their supervisor to be supportive of them were less likely to think about leaving their job.

Due to the ample research findings that has shown that perceived supervisor support is significantly and negatively related to turnover intention, researchers have set out to understand the mechanisms of this relationship. Examination of mediators of the relationship between perceived supervisor support and turnover intention is important because turnover intention has costly implications for organizations, and it is important to understand why perceived supervisor support is associated with lower turnover intention. When researchers (Nichols et al., 2016; Shuck et al., 2014) tried to identify a potential mechanism of the relationship between perceived supervisor support and turnover intention, they have often used social exchange theory to explain the mechanism of the relationship.

\section{Social Exchange Theory}

According to social exchange theory (Blau, 1964), social exchanges are based on the exchange of benefits between parties. Individuals enter and remain in exchange relationships as long as costs do not outweigh benefits. Social exchanges are marked by a level of investment in which benefits and reciprocations are exchanged over a long-term, 
open-ended period (Colquitt \& Zipay, 2015). In social exchanges, benefits tend to be unspecified and intangible. Examples of benefits include things like assistance, advice, and appreciation (Colquitt \& Zipay, 2015). Perceived support from one's supervisor is considered to be a benefit that causes a deepening of exchange relationships. Once the deepening of the relationship occurs, employees are likely to reciprocate the benefits in the form of more positive job attitudes and behaviors due to the norm of reciprocity. In other words, employees feel obligated to repay positive treatments from their supervisors with beneficial attitudes and/or behaviors.

Using social exchange theory, researchers have identified several mediating variables. For example, Stinglhamber and Vandenberghe (2003) identified affective commitment to the supervisor as a mechanism to explain the relationship between perceived supervisor support and turnover intention. Affective commitment to the supervisor was defined as "an attachment characterized by an identification and emotional attachment to the supervisor" (Clugston, Howell, \& Dorfman, 2000; Stinglhamber \& Vandenberghe, 2003). More specifically, they hypothesized that affective commitment to the supervisor would mediate the negative relationship between perceived supervisor support and turnover. Results supported the hypothesis. The researchers found that the more an employee perceived their supervisor to support them, the more they felt affectively committed to their supervisor, which in turn led to lower turnover intention.

Similarly, using social exchange theory, Nichols et al. (2016) investigated the mediating role of affective organizational commitment on the relationship between perceived supervisor support and the intention to leave. The researchers sampled 270 
frontline service employees in two hospitals in the United States. Results indicated that affective organizational commitment fully mediated the relationship between perceived supervisor support and the intention to leave. These findings indicate that when employees perceive their supervisors to be supportive, they are more affectively committed to their organization, which in turn leads to less intention to turnover.

While affective commitment to the supervisor and affective organizational commitment have been researched as mediators between perceived supervisor support and turnover intention, work engagement has received less attention. Prior research has investigated the relationship between perceived supervisor support and intention to leave through the lens of social-exchange theory, but little attention has been paid to the mediating role of work engagement on this relationship using the JD-R model.

\section{Job Demands-Resources (JD-R) Model}

The Job Demands-Resources (JD-R) model states that job resources lead to work engagement, which, in turn, lead to a multitude of positive outcomes through a motivational process (Bakker, Demerouti, \& Euwema, 2005; Demerouti, Bakker, Nachreiner, \& Schaufeli, 2001; Schaufeli \& Bakker, 2004). The model proposes that job resources drive work engagement because they serve both intrinsic and extrinsic motivational roles. Some of the positive outcomes of work engagement include increased in-role and extra-role performance, greater creativity, and reduced turnover intention (Bakker \& Demerouti, 2008).

Work engagement. Work engagement has been defined in many different ways throughout the literature. For example, Kahn (1990) conceptualized work engagement as 
the "harnessing of the organizational members' selves in their work roles, expressed cognitively, affectively, and physically" (p. 7). Engaged employees invest their physical, cognitive, and emotional energies into their role performance (Kahn, 1990; Crawford, LePine, \& Rich, 2010). That is, engaged employees become energetic in their work, focused and attentive, and are emotionally invested in their work (Kahn, 1990).

According to Schaufeli, Salanova, González-Romá, and Bakker (2002), work engagement is defined as a "positive, fulfilling, work-related state of mind that is characterized by vigor, dedication, and absorption" (p. 6). Vigor is defined as the willingness to invest effort in one's role, exhibit high levels of energy, and persistence even in the face of difficulties. Dedication is characterized by a sense of enthusiasm, pride, and challenge. The state of absorption is when one is deeply engrossed in their work and time passes quickly, often having difficulties detaching oneself from work. According to this definition, when employees are engaged, they feel compelled to strive toward a challenging goal, bring their personal energy to work, and are intensely involved in work through enthusiastically applying such energy (Maslach, Schaufelli, \& Leiter, 2001).

While Kahn (1990) and Schaufeli et al. (2002) are the two groups of researchers who have provided the most widely used definitions of work engagement, other scholars have also contributed towards the definition of work engagement. For example, work engagement encompasses an employees' affective commitment to the organization (Baumruk, 2004; Rhoades, Eisenberger, \& Armeli, 2001). Work engagement is also defined as the extent to which employees are cognitively, emotionally, and mentally 
committed to their organization, often displayed by the amount of discretionary effort they exhibit in their job (Frank, Finnegan, \& Taylor, 2004; Macey \& Schneider, 2008; Saks, 2006; Ware, 2012).

Considering that work engagement has been defined in several different ways in the literature, the definition of work engagement for this study includes components from a few different scholars. In the present study, I define work engagement as the willingness to invest high levels of energy and discretionary effort in one's role, a sense of pride in one's work, and the investment of one's physical, cognitive, and emotional energies in one's role (Frank et al., 2004; Harter, Schmidt, \& Hayes, 2002; Kahn, 1990; Macey \& Schneider, 2008; Crawford, LePine, \& Rich, 2010; Schaufeli et al., 2002; Ware, 2012).

Predictors of work engagement. According to the JD-R model, predictors of work engagement are job resources. Job resources refer to physical, psychological, social, or organizational aspects of a job that may (a) be functional in achieving work goals; (b) reduce job demands and the associated physiological and psychological costs; and (c) stimulate personal growth and development (Demerouti et al., 2001). Job resources can play both an intrinsic motivational and an extrinsic motivational role. They play an intrinsic motivational role because they foster employees' growth, learning and development, and fulfill basic human needs (Bakker \& Demerouti, 2008). Job resources can also play an extrinsic motivational role because they are instrumental in achieving work goals (Bakker \& Demerouti, 2008). Example of job resources identified in the JD-R model include job autonomy, social support from co-workers, feedback, opportunities for development, task variety, job security, and role clarity (Schaufeli \& Bakker, 2004). In a 
meta-analysis by Crawford, LePine, and Rich (2010), the researchers identified several job resources that were positively related to work engagement, such as job autonomy, feedback, opportunities for development, and job variety. Similarly, Halbesleben (2010) also found that autonomy, social support, and feedback were positively related to work engagement. These findings indicate that people become engaged when job resources exist.

Perceived supervisor support. Supervisor support has also been widely identified as a job resource in the literature (Demerouti et al., 2001; Leiter \& Maslach, 1988; Saks, 2006). Supervisor support includes opportunities for development, performance feedback, and the interest in employees' career goals (Bakker, Demerouti, \& Verbeke, 2004; Demerouti et al., 2001; Kraimer \& Wayne, 2004). The present study focuses on perceived supervisor support as a job resource because employees who perceive their supervisor as supportive are likely to be motivated both intrinsically and extrinsically in their jobs. Consistent with the JD-R model, perceived supervisor support plays an extrinsic motivational role as employees get the job done if they receive support from their supervisor. Furthermore, supervisor support indicates that employees are valued and cared by their supervisors, thus, employees are likely to be intrinsically motivated if they feel their supervisor are supportive because supervisory support stimulates their personal growth and development, and fulfills basic human needs (e.g., self-esteem, affiliation).

The literature has consistently found that perceived supervisor support positively influences work engagement (Bailey, Madden, Alfes, \& Fletcher, 2017; Bakker et al., 2004; Jose \& Mampilly, 2015; Lee \& Eissenstat, 2018; Sarti, 2014). For example, in 
several meta-analyses, Halbesleben (2010) and Bailey et al. (2017) found that supervisor support was positively related to work engagement. Furthermore, Freeney and Fellenz (2013) hypothesized that job resources, such as support from supervisors, motivates employees to become more engaged. The researchers found that support from supervisors was positively related to work engagement. In a study by Lee and Eissenstat (2018), the researchers sampled 1,997 employees of multinational companies and found perceived supervisor support was significantly and positively related to work engagement for both men and women. These findings indicate that employees who feel they have support from their supervisor tend to be more engaged in their work.

Consequences of work engagement. There are many consequences of work engagement identified in the literature. Some of the most commonly researched outcomes of work engagement include performance, organizational commitment, and job satisfaction. For example, Harter, Schmidt, and Hayes (2002) conducted a meta-analysis that sampled more than 190,000 employees from 7,900 different business units in a variety of industries and companies and found a positive relationship between work engagement and business outcomes (e.g., profit, turnover, customer satisfaction-loyalty) at the business-unit level, indicating that business units with engaged employees are likely to have an increase in productivity, profitability, and customer satisfaction.

Organizational commitment has also been identified as an outcome of work engagement. Halbesleben (2010) conducted a meta-analysis and found a positive relationship between work engagement and organizational commitment. These findings 
indicate that the more engaged employees are, the more likely they are to be committed to their organization.

The literature has also found job satisfaction to be a consequence of work engagement. Research has identified a positive relationship between work engagement and job satisfaction (Bailey et al., 2017; Biswas and Bhatnagar, 2013; Yalabik et al., 2013). These findings show that employees who are more engaged in their job are more likely to be satisfied with their job.

Organizational citizenship behaviors have also been linked with work engagement. Organizational citizenship behaviors are defined as "performance that supports the social and psychological environment in which task performance takes place" (Organ, 1997, p. 95). Research has found a positive relationship between work engagement and organizational citizenship behaviors (Mauno, Kinnunen, Mäkikangas \& Feldt, 2011; Crawford, LePine, \& Rich, 2010). These findings indicate that the more engaged employees are, the more likely they are to engage in these discretionary extra-role behaviors.

Research has also shown that turnover intention is one of the outcomes of work engagement (Bailey et al., 2017; Bakker, Demerouti, \& Schaufeli, 2005; Halbesleben, 2010; Karatepe, Yavas, Babakus, \& Deitz, 2018; Saks, 2006; Schaufeli \& Bakker, 2004). In a more recent study, Karatepe et al. (2018) conducted a study of 183 employees in the hotel industry. The researchers found that work engagement was significantly and negatively related to turnover intention. Furthermore, meta-analyses on the relationship between work engagement and turnover intention show a strong and negative relationship 
between work engagement and turnover intention (Bailey et al., 2017; Halbesleben, 2010). These findings indicate that if employees are engaged in their work, they are less likely to develop an intention to leave their organization.

Although the JD-R model proposes that work engagement acts as a mediator of the relationship between job resources and outcomes, to my knowledge, no studies have examined work engagement as a mediator of the relationship between perceived supervisor support and turnover intention using the JD-R model. Indirect evidence comes from research that used similar, yet different, constructs to perceived supervisor support, but still used social exchange theory as the mechanism to explain the relationship between social support and turnover intention. Shuck et al. (2014) proposed that social exchange theory offers a theoretical bridge that supports the possible mediating role of work engagement on the relationship between perceived support for participation in human resource development (HRD) practices and turnover intention. Perceptions of support related to HRD practices include career development, leadership development, and workplace learning and performance. Results showed that work engagement partially mediated the relationship between perceived support for participation in HRD and turnover intention. That is, when an employee believed their organization invested in and was supportive of them through human resource development practices, they were obligated to become more engaged, which in turn led to lower levels of turnover intention.

Similarly, Kumar, Jauhari, Rastogi, and Sivakumar (2018) studied work engagement as a mediator of the relationship between manager support for development and turnover 
intention. The researchers' definition of "manager support for development" included three different aspects: perceived supervisor support, managerial support, and familysupportive supervisor behaviors. This study also examined the mechanism of this relationship through the lens of the social-exchange theory. The researchers found that work engagement mediated the relationship between manager support for development and turnover intention, such that employees who had a manager who supported their development were more engaged in their work, which in turn reduced the employee's intention to leave their job.

These studies showed that work engagement was a mechanism of the relationship between perceived supervisor support and turnover intention, and suggest that people become engaged as a felt obligation to perceived supervisor support, which then leads to less intention to turnover. However, using the JD-R model, I also argue that people become engaged because perceived support from their supervisor is a job resource that motivates them extrinsically and intrinsically, which then leads to less intention to turnover. Perceived supervisor support motivates employees extrinsically because with supervisor support, the job gets done. Furthermore, if employees are valued and cared for by their supervisors, they are likely to be intrinsically motivated because supervisor support could stimulate their personal growth and development, and fulfil basic human needs.

Because work engagement is negatively related to turnover intention, organizations can focus on increasing the job resource of perceived supervisor support in order to 
motivate employees to be more engaged, which will ultimately reduce the likelihood of them leaving the organization.

Therefore, I hypothesize the following.

Hypothesis. Work engagement will mediate the relationship between perceived supervisor support and turnover intention, such that perceived supervisor support will be positively related to work engagement, which in turn will be negatively related to turnover intention.

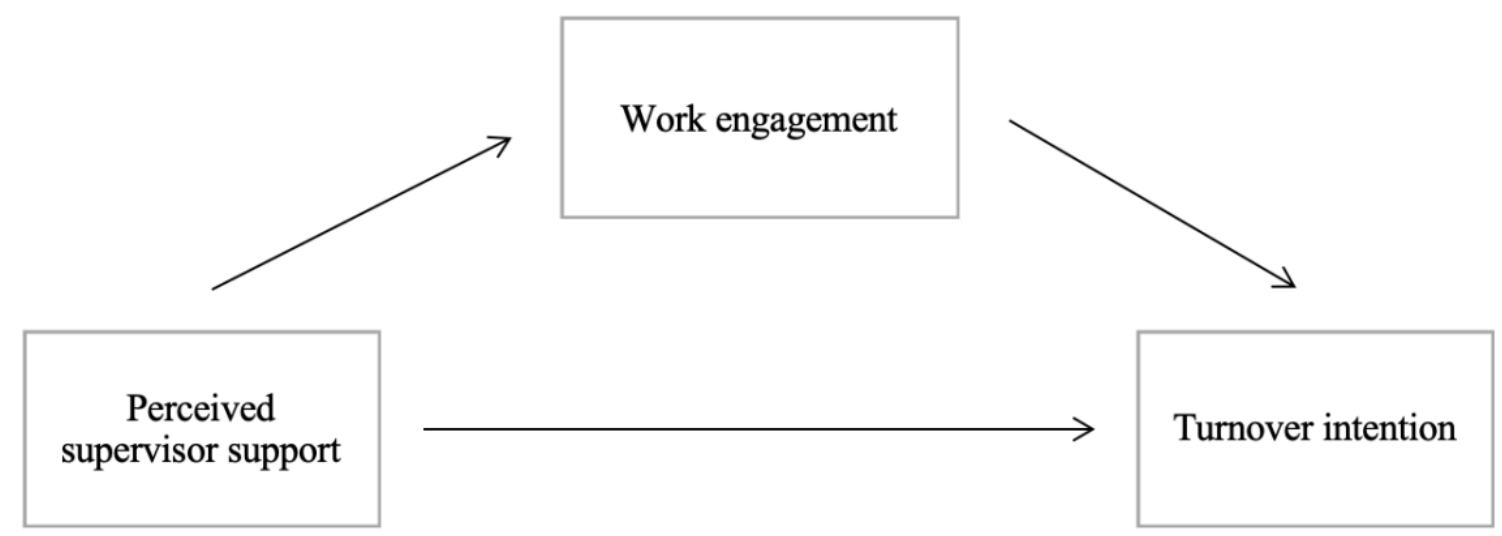

Figure 1. Work engagement as a mediator of the relationship between perceived supervisor support and turnover intention

\section{Present Study}

The present study investigates the mediating role of work engagement on the relationship between perceived supervisor support and turnover intention. Although prior literature has looked at this relationship through the lens of the social-exchange theory, the present study is the only study to my knowledge that investigates the relationship between perceived supervisor support and turnover intention using the JD-R model. I 
propose that the relationship between perceived supervisor support and turnover intention can be explained by the motivational processes of work engagement. Using the JD-R model theoretical framework, I propose that perceived supervisor support is a resource that leads to work engagement because employees are motivated both intrinsically and extrinsically by the support they receive from their supervisor, rather than through the norm of reciprocity. Perceived supervisor support is a job resource that organizations can ultimately increase if more support from supervisors is needed to help employees be more engaged. With the support of their supervisors, employees will be more intrinsically and extrinsically engaged through this motivational process of engagement, and they will be less likely to intend on leaving their job. 


\section{Method}

\section{Participants}

Data were collected in 2019 using a company-wide engagement survey. The sample consisted of employees at a healthcare organization in Northern California. In order to be included in the survey, all 2,129 full-time employees were invited to take the survey. Among them, 1,098 employees participated in the survey, resulting in a 51.6\% response rate. After identifying outliers and eliminating participants with excessive missing data, the final sample consisted of 954 employees.

Demographic information of the sample is reported in Table 1. The sample consisted of $72.5 \%$ female and $27.5 \%$ male. With respect to the age of participants, $43.6 \%$ were in the age range of $30-44$, followed by $24.0 \%$ between $45-54,21.0 \%$ for ages 55 and over, and $11.4 \%$ under 30 years of age. In terms of the ethnic composition of the sample, Asians (39.2\%) represented the largest ethnic group, followed by White (29.0\%), Hispanic or Latino (17.9\%), and Black or African American (9.6\%). Tenure of participants was widely distributed, with the largest group having 1-3 years (26.4\%), followed by the second largest group having 10 years and over $(22.0 \%)$. 
Table 1

Demographic Characteristics of Participants $(N=954)$

\begin{tabular}{|c|c|c|}
\hline Variable & $n$ & $\%$ \\
\hline \multicolumn{3}{|l|}{ Gender } \\
\hline Male & 262 & $27.5 \%$ \\
\hline Female & 692 & $72.5 \%$ \\
\hline \multicolumn{3}{|l|}{ Age } \\
\hline Under 30 & 109 & $11.4 \%$ \\
\hline 30 to 44 years & 416 & $43.6 \%$ \\
\hline 45 to 54 years & 229 & $24.0 \%$ \\
\hline 55 and over & 200 & $21.0 \%$ \\
\hline \multicolumn{3}{|l|}{ Ethnicity } \\
\hline Asian & 374 & $39.2 \%$ \\
\hline White & 277 & $29.0 \%$ \\
\hline Hispanic or Latino & 171 & $17.9 \%$ \\
\hline Black or African American & 92 & $9.6 \%$ \\
\hline Two or more races & 20 & $2.1 \%$ \\
\hline Native Hawaiian or other Pacific Islander & 16 & $1.7 \%$ \\
\hline American Indian/Native Alaskan & 4 & $.4 \%$ \\
\hline \multicolumn{3}{|l|}{ Tenure } \\
\hline Less than 90 days & 61 & $6.4 \%$ \\
\hline 90 days to 1 year & 106 & $11.1 \%$ \\
\hline 1 to 3 years & 252 & $26.4 \%$ \\
\hline 3 to 5 years & 134 & $14.0 \%$ \\
\hline 5 to 10 years & 191 & $20.0 \%$ \\
\hline 10 years and over & 210 & $22.0 \%$ \\
\hline
\end{tabular}

\section{Measures}

Perceived supervisor support. Perceived supervisor support is defined as the degree to which supervisors value their employees' contributions and care about their well-being (Eisenberger et al., 2002; Kottke \& Sharafinski; 1988). Perceived supervisor support was 
measured with 12 items. Examples of the items were, "My manager gathers my input when making decisions that affect me," "My manager fosters genuine and trusting relationships on the team," and "My manager supports my professional growth and development." Perceived supervisor support was measured using a 5-point Likert scale of agreement (1 = Strongly Disagree, 5 = Strongly Agree $)$. Responses were averaged to create a composite score. Higher scores indicated that the employee perceived their supervisor to be more supportive. Cronbach's alpha was .97, indicating high reliability.

Work engagement. Work engagement is defined in this study as the investment of the employee's physical, cognitive, and emotional energies in their role, a sense of pride in their work, and the willingness to exhibit discretionary effort in their job (Frank et al., 2004; Harter, Schmidt, \& Hayes, 2002; Kahn, 1990; Macey \& Schneider, 2008; Crawford, LePine, \& Rich, 2010; Schaufeli et al., 2002; Ware, 2012). Work engagement was measured with 12 items. Examples of the items were, "On most days, I feel energized when I am at work," "I am proud to work for my organization," and "I feel motivated to go the extra mile." These items were measured on a 5-point Likert scale of agreement $(1=$ Strongly Disagree, 5 = Strongly Agree $)$. Responses were averaged to create a composite score. Higher scores indicated that employees were more engaged in their job. Cronbach's alpha was .93 , indicating high reliability.

Turnover intention. Turnover intention is defined as an employee's "conscious and deliberate willfulness to leave the organization" (Tett \& Meyer, 1993, p. 262). Turnover intention was measured with one item, "The chances of leaving my job voluntarily during 
the next year are..." The turnover intention item was measured using a 5-point scale (i.e. $1=$ Extremely Low, $2=$ Low, 3 = Average, $4=$ Above Average, $5=$ Very High .

\section{Procedure}

The work engagement survey was conducted by an external vendor. All surveys were completed online through the external vendor's engagement survey website. All employees of the organization received an email inviting them to take the survey that included unique login credentials. Upon logging in, participants were provided with a brief explanation of the purpose of the survey and instructions on the rating scale. Instructions indicated that the survey would take between 10-15 minutes and must be completed in one sitting. A joint statement by the Chief Executive Officer and the Chief of Human Resources indicated that all responses would remain confidential and be used to improve the quality of the work experience. Employees had one month to complete the survey and participation was voluntary.

All full-time employees were eligible to complete the survey at the time of data collection. Once the employee completed the survey, responses were collected in the online survey database. Once participants were de-identified by the external vendor, the researcher obtained the data set for analyses. Data were analyzed using Statistical Package for Social Sciences (SPSS) statistical software version 26. 


\section{Results}

\section{Descriptive Statistics}

Table 2 displays the descriptive statistics of the measured variables and Pearson correlations among them. Participants reported a relatively high level of perceived supervisor support $(M=4.11, S D=.97)$, suggesting that they perceived their managers fostered genuine and trusting relationship on the team and supported their professional growth and development. Participants also reported high levels of engagement with their work $(M=4.15, S D=.74)$, indicating that employees were engaged, as they had a sense of pride in their work, were willing to invest high levels of energy and discretionary effort, and invested their physical, cognitive, and emotional energies in their role. Participants reported low levels of turnover intention $(M=2.05, S D=1.20)$. Overall, employees felt their supervisors were supportive of them, were engaged in their work, and had low turnover intentions.

Table 2

Descriptive Statistics and Pearson Correlations of Variables $(N=954)$

Variable

1. Perceived supervisor support

2. Work engagement

3. Turnover intention $\mathrm{M}$

S SD

$4.11 \quad .97$

$4.15 \quad .74 \quad .70 * * * \quad--$

2.05

Note. $* \mathrm{p}<.05, * * \mathrm{p}<.01, * * * \mathrm{p}<.001$ 


\section{Pearson Correlations}

Pearson correlations were computed to assess the strength of the relationships among the three variables. Pearson correlations are presented in Table 2. Results showed that perceived supervisor support was positively and strongly related to work engagement, $r(952)=.70, p<.001$, such that employees who perceived their supervisor to be more supportive were likely to be more engaged. Perceived supervisor support was negatively and strongly related to turnover intention, $r(952)=-.50, p<.001$, such that employees who perceived their supervisor to be more supportive were less likely to intend on leaving their organization. Work engagement was negatively and strongly related to turnover intention, $r(952)=-.62, p<.001$, indicating that the more an employee was engaged in their job, the less likely they were to intend on leaving their job. Overall, these variables were strongly related to each other.

\section{Test of Hypothesis}

A simple mediation analysis was conducted using the SPSS macro PROCESS (model 4) to test the hypothesis. This mediation analysis uses an ordinary-least-squares path analysis to determine the direct and indirect effects (Krieger \& Sarge, 2013). I used bootstrap to calculate $95 \%$ bias-corrected confidence intervals (CIs) to assess the significance of the indirect effect because this approach has better performance and statistical power compared to other mediation approaches (e.g., Sobel test, the Baron and Kenny method) (Hayes \& Preacher, 2014). An indirect effect is significant if zero is not contained in the confidence interval (Hayes \& Preacher, 2014). Following the 
recommendation of Hayes and Preacher, the bootstrap estimates were based on 10,000 bootstrap samples.

The hypothesis stated that work engagement would mediate the relationship between perceived supervisor support and turnover intention. Table 3 shows unstandardized regression coefficients, standard errors (SE), $t$ values, and 95\% CI. As expected, perceived supervisor support was negatively related to turnover intention (path $c: b=-$ $.62, t=-17.69, p<.001)$. Perceived supervisor support was positively related to work engagement (path $a: b=.54, t=30.21, p<.001$ ). Work engagement was negatively related to turnover intention (path $b: b=-.85, t=-14.86, p<.001$ ) after controlling for perceived supervisor support (see Figure 2). These findings indicated that perceived supervisor support was positively related to work engagement, which in turn was negatively related to turnover intention. Therefore, employees who perceived their supervisor to be supportive of them were more likely to be engaged in their job, which in turn reduced the likelihood of them leaving the organization.

With respect to the significance of the indirect effect, results showed that the biascorrected bootstrap CI did not contain zero (path $a b: b=-.46,95 \% \mathrm{CI}=-.54$ to -.38 ), indicating that the indirect effect was statistically significant. These results indicated that work engagement was a significant mediator of the relationship between perceived supervisor support and turnover intention. Perceived supervisor support and work engagement explained $38.92 \%$ of the variance in turnover intention. However, perceived supervisor support was still directly related to turnover intention after controlling for work engagement (path $c^{\prime}: b=-.16, t=-3.63, p<.001$ ). These results show that 
perceived supervisor support was related to turnover intention directly and indirectly through work engagement and show support for the hypothesis. These results indicate that the hypothesis was partially supported.

\section{Table 3}

The Results of the Relationship Between Perceived Supervisor Support (PSS) and Turnover Intention (TI) as Mediated by Work Engagement

\begin{tabular}{lcccc}
\hline & & & \multicolumn{2}{c}{$95 \%$ CI } \\
\cline { 4 - 5 } PSS - TI $(c)$ & $-.62(.04)$ & $-17.69 * * *$ & -.68 & -.55 \\
PSS - Engagement $(a)$ & $.54(.02)$ & $30.21 * * *$ & .50 & .57 \\
Engagement - TI $(b)$ & $-.85(.06)$ & $-14.86^{* * * *}$ & -.97 & -.74 \\
PSS - TI $\left(c^{\prime}\right)$ & $-.16(.04)$ & $-3.63 * * *$ & -.25 & -.07 \\
Indirect Effect & & & & \\
PSS - Engagement - TI $(a b)$ & $-.46(.04)$ & & -.54 & -.38 \\
\hline
\end{tabular}

Note: This table shows the path coefficients and indirect effect for the relationship between perceived supervisor support (PSS) and turnover intention (TI) as mediated by work engagement. $* * * \mathrm{p}<.001$ 
Figure 2
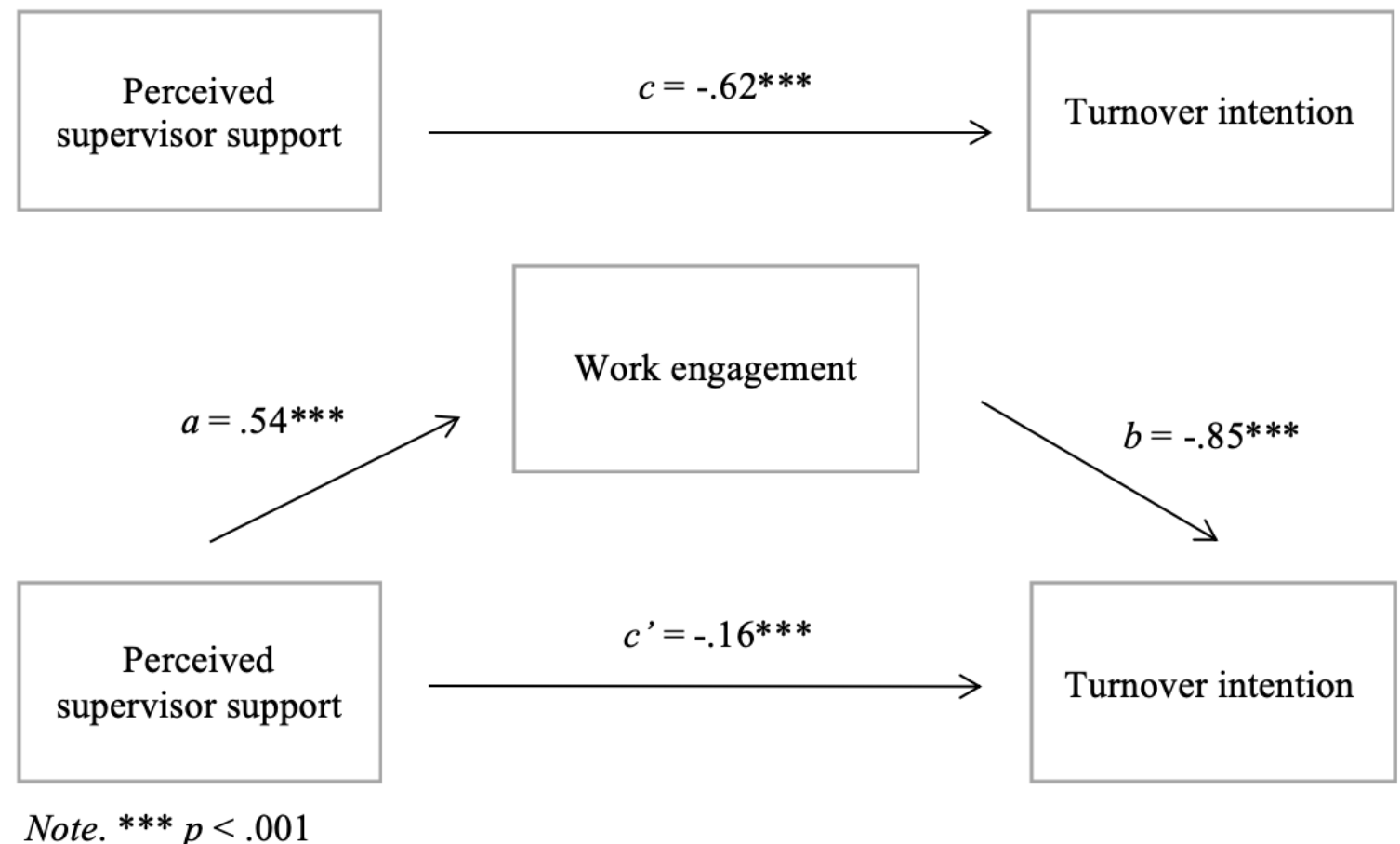

Figure 2. A simple mediation model with work engagement as the proposed mediator of the relationship between perceived supervisor support and turnover intention 


\section{Discussion}

Due to the costly implications of turnover, researchers have been attempting to identify the predictors of turnover. The literature has identified turnover intention to be one of the strongest predictors of turnover (Allen, Bryan, \& Vardaman, 2010). Research has also found perceived supervisor support to be a strong predictor of turnover intention (Karatepe, 2014; Kim \& Jogaratnam, 2010; Nichols, Swanberg, \& Bright, 2016).

Although perceived supervisor support has consistently been shown to be negatively related to turnover intention, little is known about the potential mechanism of this relationship.

Past research has shown perceived obligations derived from social exchange theory as an underlying mechanism of the relationship between perceived supervisor support and turnover intention (Kumar et al., 2018; Shuck et al., 2014). The present study argued that based on JD-R theory, motivational process of work engagement might also be an explanatory mechanism for the relationship between perceived supervisor support and turnover intention. More specifically, the present study proposed that perceived supervisor support would act as a job resource that motivates employees to be engaged with their work, which in turn would be negatively related to turnover intention.

\section{Summary of Findings}

The hypothesis stated that work engagement would mediate the relationship between perceived supervisor support and turnover intention, such that perceived supervisor support would be positively related to work engagement, which in turn would be negatively related to turnover intention. Results showed that work engagement partially 
mediated the relationship between perceived supervisor support and turnover intention. This partial mediation implies that there was a significant relationship between work engagement and turnover intention, but also a significant relationship between perceived supervisor support and turnover intention. Results showed that perceived supervisor support was directly related to turnover intention. These results showed partial support to the hypothesis.

\section{Theoretical Implications}

Prior literature has investigated the relationship between perceived supervisor support and turnover intention through the lens of social-exchange theory (Kumar et al., 2018; Shuck et al., 2014). Perceived supervisor support is considered to be a benefit that causes a deepening of exchange relationships between an employee and his or her supervisor. Employees are likely to reciprocate the benefits of an exchange relationship with their supervisor and feel obligated to repay positive treatments with beneficial attitudes and/or behaviors.

Although the literature has identified social exchange theory as the explanatory mechanism in the relationship between supportive supervisors and turnover intention, the present study investigated this relationship through the lens of the JD-R model, where I hypothesized that perceived supervisor support is a job resource that is positively related to work engagement, which, in turn, is related to less turnover intention through a

motivational process (Bakker, Demerouti, \& Euwema, 2005; Demerouti, Bakker, Nachreiner, \& Schaufeli, 2001; Schaufeli \& Bakker, 2004). Using the JD-R theoretical framework, the current study demonstrated that the relationship between perceived 
supervisor support and turnover intention could also be explained by the motivational processes of work engagement.

To my best knowledge, this is the first study that examined the mediating role of work engagement on the relationship between perceived supervisor support and turnover intention through the lens of the JD-R model. Supportive supervisors play an intrinsic motivational role because they foster employees' growth, learning and development, and fulfill basic human needs (Bakker \& Demerouti, 2008). They can also play an extrinsic motivational role because they are instrumental in achieving work goals (Bakker \& Demerouti, 2008). Results of this study indicate that individuals become engaged because they are motivated both intrinsically and extrinsically by a supportive supervisor, which in turn reduces the likelihood they intend on leaving the organization. Using the JD-R theoretical framework, the present study demonstrates that a job resource was associated with turnover intention through work engagement. As perceived supervisor support has consistently been identified as a job resource, it may be possible to influence turnover intention by increasing supportive supervisor practices that lead to motivated and engaged employees.

Furthermore, consistent with prior literature, the present study found that perceived supervisor support was significantly and negatively related to turnover intention (Gordon et al., 2019; Kim \& Kao, 2014; Nichols et al., 2016). These findings indicate that the more employees perceived their supervisor to be supportive of them, the less likely they intended on leaving the organization. Additionally, results also showed that work engagement was negatively related to turnover intention, such that the more employees 
were engaged in their job, the less likely they intended on leaving the organization. These findings show additional empirical evidence that both perceived supervisor support and work engagement were consistently and negatively related to turnover intention (Bailey et al., 2017; Bakker, Demerouti, \& Schaufeli, 2005; Halbesleben, 2010; Karatepe et al., 2018; Saks, 2006; Schaufeli \& Bakker, 2004).

\section{Practical Implications}

The present study has some practical implications for organizations seeking to address issues with turnover. Results of the present study showed that employees developed less intention to turnover because support from their supervisor may have motivated employees to become more engaged in their job. Employees view their supportive supervisor as a resource that motivates them to become more engaged. As supervisor support has consistently been identified as a job resource in the literature (Demerouti et al., 2001; Leiter \& Maslach, 1988; Saks, 2006), organizations can focus on influencing people's intention to turnover, not only through social exchange, but also through job resources and the motivational process of engagement.

In a meta-analysis, Knight, Patterson, and Dawson (2017) found that job resource building was an intervention that was positively related to work engagement. Given these findings, organizations can focus on training and interventions to instill more supportive supervisor practices. By focusing on increasing the job resource of perceived supervisor support, employees may become more engaged, which in turn may reduce the likelihood of them intending on leaving their organization. 
There are three effective strategies organizations and supervisors can adopt to deal with turnover intentions. In order to increase the resource of perceived supervisor support, organizations can implement a developmental track for all employees that includes training for the knowledge, skills, and abilities to be successful in the role, and provide clear direction for upward mobility in the organization. Supervisors assist their subordinates in gaining capabilities for future opportunities. A supervisor's involvement in an employee's developmental track may intrinsically motivate employees to become more engaged because they feel valued and supported, which might help to reduce the likelihood of the employee leaving the organization.

Furthermore, employees are intrinsically motivated because they feel valued and cared for by a supportive supervisor. Employees are likely to be intrinsically motivated because a supportive supervisor stimulates personal growth and development and fulfills basic human needs (e.g., self-esteem, affiliation). Supportive supervisor practices also include supervisors who are invested and interested in their subordinates' career growth. Supervisors who share the responsibility with their employees regarding their career growth track are often perceived to be supportive. Honest and regular communication between the employee and supervisor about career growth opportunities may motivate employees to become more engaged. By increasing supervisor support, employees may become more intrinsically motivated because they feel valued and cared for by their supervisor, which in turn may reduce the likelihood of them leaving the organization.

Supportive supervisors can also play an extrinsic motivational role because they are instrumental in achieving work goals (Bakker \& Demerouti, 2008). In order to 
extrinsically motivate employees, organizations and supervisors can implement a holistic rewards and recognition program (Jex \& Britt, 2008) It may be necessary to have a balance between intangible and tangible rewards. Intangible rewards include timely and sincere recognition, awards, and praise. Tangible rewards often include monetary compensation for meeting performance goals. Supervisors can play an integral role in delivering these rewards and recognition to their subordinates to increase the perception of supportive supervisor practices. Organizations and supervisors can extrinsically motivate employees through an effective rewards and recognition program, which ultimately will lead to more engaged employees, thus reducing the likelihood of employees intending on leaving the organization.

\section{Strengths and Weaknesses of the Present Study, and Future Directions}

The present study has several strengths. The current study was the first study to examine the mediating role of work engagement on the relationship between perceived supervisor support and turnover intention using the JD-R theoretical framework. The present study demonstrated that the mechanism that explained this relationship was through the motivational processes of engagement, in addition to a felt obligation or norm of reciprocity based on social exchange theory.

Another strength of this study was a large sample size. A large sample size increases the likelihood of achieving statistical significance and captures a stronger representation of the population. Thus, the results of the present study may be generalizable to the overall population of people working in the healthcare industry. 
Despite the several strengths of this study, there were a few weaknesses. The response rate of the current study was $51.6 \%$, indicating a relatively low response rate. It may be possible that employees who were more motivated to complete the survey may have been more engaged and motivated employees overall. In order to increase the response rate in future studies, the researchers could either make the survey mandatory, expand the time frame to complete the survey, or provide employee incentives for completing.

As the study was non-experimental, causal statements between the variables cannot be made. Therefore, I am not able to conclude that perceived supervisor support causes employees to be engaged, which in turn, leads them to develop less intention to leave their organization. Future research could identify a causal pathway by administering the survey before and after an intervention. In order to conduct a longitudinal study, future research could administer the survey prior to the participants undergoing a job resource building intervention. After the participants have received an intervention designed to increase perceived supervisor support, the researchers can administer the same survey post-intervention and compare the results in order to identify a causal pathway.

Additionally, the data in this study were collected from the same organization in the healthcare industry. Therefore, this study can only be generalizable to the healthcare industry, and not necessarily the general population of various industries. Future research should be directed at collecting data from a multitude of industries in order to be more representative of the general population. 
Sampling from a multitude of different industries might also address another weakness to the study, which was that the sample consisted of more females than males. This uneven distribution of gender may be due to the nature of the industry itself, as the healthcare industry is currently predominantly female (Joyce, 2018). Although a more even distribution of gender would be more representative of the overall population, a female majority may be more representative of the healthcare industry as a whole.

Future research could examine if work engagement acts as a mediator of the relationship between perceived supervisor support and other outcomes. Some outcomes that have been identified in the work engagement literature are productivity, profitability, and customer satisfaction (Harter, Schmidt, \& Hayes, 2002). By investigating other performance indicators, such as profitability and customer satisfaction levels, organizations could use those findings to evaluate manager effectiveness or develop training to strengthen leadership capability in order to motivate employees to become more engaged.

Considering the present study only investigated engagement as a mediator of the relationship between perceived supervisor support and turnover intention, future research could expand by studying different job and personal resources, and other outcomes. Other job resources identified in the JD-R model to consider in future research include job autonomy, social support from co-workers, task variety, job security, and role clarity (Schaufeli \& Bakker, 2004). Some personal resources include optimism, resiliency, selfefficacy, and self-esteem (Bakker \& Demerouti, 2008). As this study has identified work engagement as a mediator in the relationship between a job resource and outcome using 
the JD-R model, future research may explore other job resources that motivate employees to become more engaged, which ultimately should lead to a multitude of positive outcomes.

\section{Conclusion}

The present study investigated the mediating role of work engagement on the relationship between perceived supervisor support and turnover intention. This study is the first study to the best of my knowledge that investigates the relationship between perceived supervisor support and turnover intention using the JD-R model. Using the JD$\mathrm{R}$ model theoretical framework, I found that perceived supervisor support was a resource that was related to work engagement because employees were motivated both intrinsically and extrinsically by the support they receive from their supervisor, rather than through social exchange as identified in prior literature, which was then negatively related to turnover intention. Perceived supervisor support is a job resource that organizations can increase if more support from supervisors is needed to help employees become more engaged. Supportive supervisors will motivate employees both intrinsically and extrinsically to become engaged, and they will be less likely to have turnover intentions. 


\section{References}

Allen, D. G., Bryant, P. C., \& Vardaman, J. M. (2010). Retaining talent: Replacing misconceptions with evidence-based strategies. The Academy of Management Perspectives, 24, 48-64. http://doi-org.libaccess.sjlibrary.org/10.5465/ AMP.2010.51827775

Allen, N. J., \& Meyer, J. P. (1996). Affective, continuance, and normative commitment to the organization: An examination of construct validity. Journal of Vocational Behavior, 49, 252-276. http://doi.org/10.1006/jvbe.1996.0043

Bailey, C., Madden, A., Alfes, K., \& Fletcher, L. (2017). The meaning, antecedents and outcomes of employee engagement: A narrative synthesis. International Journal of Management Reviews, 19, 31-53. http://doi-org.libaccess.sjlibrary.org/10.1111/ ijmr.12077

Bakker, A. B., \& Demerouti, E. (2008). Towards a model of work engagement. The Career Development International, 13, 209-223. http://doiorg.libaccess.sjlibrary.org/10.1108/13620430810870476

Bakker, A. B., Demerouti, E., \& Euwema, M. C. (2005). Job resources buffer the impact of job demands on burnout. Journal of Occupational Health Psychology, 10, 170-180. http://doi-org.libaccess.sjlibrary.org/10.1037/1076-8998.10.2.170

Bakker, A. B., Demerouti, E., \& Schaufeli, W. B. (2005). The crossover of burnout and work engagement among working couples. Human Relations, 58, 661-689. http://doi.org/10.1177/0018726705055967

Bakker, A. B., Demerouti, E., \& Verbeke, W. (2004). Using the job demands-resources model to predict burnout and performance. Human Resource Management, 43, 83-104. http://doi.org/10.1002/hrm.20004

Baumruk, Ray. (2004). The missing link: The role of employee engagement in business success. Workspan, 47, 48-52. Retrieved from http://search.proquest.com.libaccess.sjlibrary.org/docview/194712679?accountid=103 61

Biswas, S., \& Bhatnagar, J. (2013). Mediator analysis of employee engagement: Role of perceived organizational support, P-O fit, organizational commitment and job satisfaction. Vikalpa, 38, 27-40. http://doi.org/10.1177/0256090920130103

Blau, P. M. (1964). Exchange and power in social life. New York: Wiley. 
Brown, C., \& Medoff, J. (1978). Trade unions in the production process. Journal of Political Economy, 86, 355-378. http://doi.org/10.1086/260677

Cascio, W. F. (2006). Managing human resources: Productivity, quality of work life, profits. Boston: McGraw-Hill/Irwin.

Chang, W. A., Wang, Y., \& Huang, T. (2013). Work design-related antecedents of turnover intention: A multilevel approach. Human Resource Management, 52, 1-26. http://doi-org.libaccess.sjlibrary.org/10.1002/hrm.21515

Clugston, M., Howell, J. P., \& Dorfman, P. W. (2000). Does cultural socialization predict multiple bases and foci of commitment? Journal of Management, 26, 5-30. http://doi-org.libaccess.sjlibrary.org/10.1016/S0149-2063(99)00034-3

Colquitt, J. \& Zipay, K. (2014). Justice, fairness, and employee reactions. Annual Review of Organizational Psychology and Organizational Behavior, 2, 7599. http://doi.org/10.1146/annurev-orgpsych-032414-111457

Crawford, E. R., LePine, J. A., \& Rich, B. L. (2010). Job engagement: Antecedents and effects on job performance. Academy of Management Journal, 53, 617-635. http://doi-org.libaccess.sjlibrary.org/10.5465/AMJ.2010.51468988

Demerouti, E., Bakker, A. B., Nachreiner, F., \& Schaufeli, W. B. (2001). The job demands-resources model of burnout. Journal of Applied Psychology, 86, 499512. http://doi-org.libaccess.sjlibrary.org/10.1037/0021-9010.86.3.499

Eisenberger, R., Stinglhamber, F., Vandenberghe, C., Sucharski, I. L., \& Rhoades, L. (2002). Perceived supervisor support: Contributions to perceived organizational support and employee retention. Journal of Applied Psychology, 87, 565-573. http://doi-org.libaccess.sjlibrary.org/10.1037/0021-9010.87.3.565

Feyerabend, R., Herd, A. M., \& Choi, N. (2018). Job satisfaction and turnover intentions among Indian call center agents: Exploring the role of emotional intelligence. The Psychologist-Manager Journal, 21, 106-129. http://doi-org.libaccess.sjlibrary.org/ $10.1037 / \mathrm{mgr} 0000071$

Frank, F., Finnegan, R., \& Taylor, C. (2004). The race for talent: Retaining and engaging workers in the 21st century. Human Resource Planning, 27, 12-25. Retrieved from http://citeseerx.ist.psu.edu/viewdoc/download?doi=10.1.1.514.4132\&rep=rep1\&type $=$ pdf 
Freeney, Y., \& Fellenz, M. R. (2013). Work engagement, job design and the role of the social context at work: Exploring antecedents from a relational perspective. Human Relations, 66, 1427-1445. http://doi.org/10.1177/0018726713478245

Freund, A. (2005). Commitment and job satisfaction as predictors of turnover intentions among welfare workers. Administration in Social Work, 29, 5-21. http://doiorg.libaccess.sjlibrary.org/10.1300/J147v29n02_02

Gordon, S., Tang, C-H., Day, J., \& Adler, H. (2019). Supervisor support and turnover in hotels: Does subjective well-being mediate the relationship? International Journal of Contemporary Hospitality Management, 31, 496-512. http://doiorg.libaccess.sjlibrary.org/10.1108/IJCHM-10-2016-0565

Halbesleben, J. R. B. (2010). A meta-analysis of work engagement: Relationships with burnout, demands, resources, and consequences. In A. B. Bakker (Ed.), Work engagement: A handbook of essential theory and research. (pp. 102-117). Psychology Press.

Harter, J. K., Schmidt, F. L., \& Hayes, T. L. (2002). Business-unit-level relationship between employee satisfaction, employee engagement, and business outcomes: A meta-analysis. Journal of Applied Psychology, 87, 268-279. http://doiorg.libaccess.sjlibrary.org/10.1037/0021-9010.87.2.268

Hausknecht, J. P., \& Trevor, C. O. (2011). Collective turnover at the group, unit, and organizational levels: Evidence, issues, and implications. Journal of Management, 37, 352-388. http://doiorg.libaccess.sjlibrary.org/10.1177/0149206310383910

Hayes, A. F., \& Preacher, K. J. (2014). Statistical mediation analysis with a multicategorical independent variable. British Journal of Mathematical and Statistical Psychology, 67, 451-470. http://doiorg.libaccess.sjlibrary.org/10.1111/bmsp.12028

Heavey, A. L., Holwerda, J. A., \& Hausknecht, J. P. (2013). Causes and consequences of collective turnover: A meta-analytic review. Journal of Applied Psychology, 98, 412453. http://doi-org.libaccess.sjlibrary.org/10.1037/a0032380

Jex, S. M., \& Britt, T. W. (2008). Organizational psychology: A scientist-practitioner approach. Hoboken, NJ: J. Wiley \& Sons. 
Jose, G., \& Mampilly, S. R. (2015). Relationships among perceived supervisor support, psychological empowerment and employee engagement in Indian workplaces. Journal of Workplace Behavioral Health, 30, 231-250. http://doiorg.libaccess.sjlibrary.org/10.1080/15555240.2015.1047498

Joyce, T. (2018). Does healthcare have a gender problem? Health eCareers. Retrieved April 22, 2020, from https://www.healthecareers.com/article/healthcarenews/does-healthcare-have-a-gender-problem

Kahn, W. A. (1990). Psychological conditions of personal engagement and disengagement at work. Academy of Management Journal, 33, 692-724. http://doi-org.libaccess.sjlibrary.org/10.2307/256287

Karatepe, O. M. (2014). The importance of supervisor support for effective hotel employees: An empirical investigation in Cameroon. Cornell Hospitality Quarterly, 55, 388-397. http://doiorg.libaccess.sjlibrary.org/10.1177/1938965513511147

Karatepe, O. M., \& Kaviti, R. (2016). Test of a mediational model of organization mission fulfillment: Evidence from the hotel industry. International Journal of Contemporary Hospitality Management, 28, 988-1008. http://doiorg.libaccess.sjlibrary.org/10.1108/IJCHM-09-2014-0464

Karatepe, O. M., Yavas, U., Babakus, E., \& Deitz, G. D. (2018). The effects of organizational and personal resources on stress, engagement, and job outcomes. International Journal of Hospitality Management, 74, 147-161. http://doi-org.libaccess.sjlibrary.org/10.1016/j.ijhm.2018.04.005

Kim, H. \& Kao, D. (2014). A meta-analysis of turnover intention predictors among U.S. child welfare workers. Children and Youth Services Review, 47, 214-223. http://doi.org/10.1016/j.childyouth.2014.09.015

Kim, K. \& Jogaratnam, G. (2010). Effects of individual and organizational factors on job satisfaction and intent to stay in the hotel and restaurant industry. Journal of Human Resources in Hospitality \& Tourism, 9, 318-339. doi:10.1080/15332845.2010.487043.

Knight, C., Patterson, M., \& Dawson, J. (2017). Building work engagement: A systematic review and meta-analysis investigating the effectiveness of work engagement interventions. Journal of Organizational Behavior, 38, 792-812. http://doi-org.libaccess.sjlibrary.org/10.1002/job.2167 
Kottke, J. L., \& Sharafinski, C. E. (1988). Measuring perceived supervisory and organizational support. Educational and Psychological Measurement, 48, 1075-1079. http://doi-org.libaccess.sjlibrary.org/10.1177/0013164488484024

Kraimer, M. L., \& Wayne, S. J. (2004). An examination of perceived organizational support as a multidimensional construct in the context of an expatriate assignment. Journal of Management, 30, 209-237. http://doi.org/10.1016/j.jm.2003.01.001

Krieger, J. L., \& Sarge, M. A. (2013). A serial mediation model of message framing on intentions to receive the human papillomavirus (HPV) vaccine: Revisiting the role of threat and efficacy perceptions. Health Communication, 28, 5-19. http://doi-org.libaccess.sjlibrary.org/10.1080/10410236.2012.734914

Kumar, M., Jauhari, H., Rastogi, A., \& Sivakumar, S. (2018). Managerial support for development and turnover intention: Roles of organizational support, work engagement and job satisfaction. Journal of Organizational Change Management, 31, 135-153. http://doi-org.libaccess.sjlibrary.org/10.1108/JOCM-062017-0232

Lee, Y., \& Eissenstat, S. J. (2018). An application of work engagement in the job demands-resources model to career development: Assessing gender differences. Human Resource Development Quarterly, 29, 143-161. http://doi-org.libaccess.sjlibrary.org/10.1002/hrdq.21310

Leiter, M. P., \& Maslach, C. (1988). The impact of interpersonal environment on burnout and organizational commitment. Journal of Organizational Behavior, 9, 297-308. http://doi.org/10.1002/job.4030090402

Ma, S. \& Trigo, V. (2008). Winning the war for managerial talent in China: An empirical study. Chinese Economy, 41, 34-57.

Macey, W.H. and Schneider, B. (2008) The meaning of employee engagement. Industrial and Organizational Psychology, 1, 3-30. http://dx.doi.org/10.1111/j.17549434.2007.0002.x

Maertz, C. P., Jr., Griffeth, R. W., Campbell, N. S., \& Allen, D. G. (2007). The effects of perceived organizational support and perceived supervisor support on employee turnover. Journal of Organizational Behavior, 28, 1059-1075. http://doiorg.libaccess.sjlibrary.org/10.1002/job.472

Maslach, C., Schaufeli, W. B., \& Leiter, M. P. (2001). Job burnout. Annual Review of Psychology, 52, 397-422. http://doi-org.libaccess.sjlibrary.org/10.1146/ annurev.psych.52.1.397 
Mauno, S., Kinnunen, U., Mäkikangas, A. \& Feldt, T. (2010). Job demands and resources as antecedents of work engagement: A qualitative review and directions for future research. In Albrecht, S. L. (Ed.). Handbook of employee engagement: Perspectives, issues, research and practice (pp. 111-128). Northampton, MA: Edwin Elgar.

Mobley, W. H., Horner, S. O., \& Hollingsworth, A. T. (1978). An evaluation of precursors of hospital employee turnover. Journal of Applied Psychology, 63, 408-414. http://doi-org.libaccess.sjlibrary.org/10.1037/0021-9010.63.4.408

Mowday, R. T., Steers, R. M., \& Porter, L. W. (1979). The measurement of organizational commitment. Journal of Vocational Behavior, 14, 224-247. http://doi-org.libaccess.sjlibrary.org/10.1016/0001-8791(79)90072-1

Newman, A., Thanacoody, R., \& Hui, W. (2012). The effects of perceived organizational support, perceived supervisor support and intra-organizational network resources on turnover intentions: A study of Chinese employees in multinational enterprises. Personnel Review, 41, 56-72. http://doiorg.libaccess.sjlibrary.org/10.1108/00483481211189947

Nichols, H. M., Swanberg, J. E., \& Bright, C. L. (2016). How does supervisor support influence turnover intent among frontline hospital workers? The mediating role of affective commitment. The Health Care Manager, 35, 266-279. http://doiorg.libaccess.sjlibrary.org/10.1097/HCM.0000000000000119

Organ, D. W. (1997). Organizational citizenship behavior: It's construct clean-up time. Human Performance, 10, 85-97. http://doi-org.libaccess.sjlibrary.org/10.1207/ s15327043hup1002_2

Rhoades, L., Eisenberger, R., \& Armeli, S. (2001). Affective commitment to the organization: The contribution of perceived organizational support. Journal of Applied Psychology, 86, 825-836. http://doi-org.libaccess.sjlibrary.org/10.1037/00219010.86 .5 .825

Saks, A. M. (2006). Antecedents and consequences of employee engagement. Journal of Managerial Psychology, 21, 600-619. http://doi-org.libaccess.sjlibrary.org/ $10.1108 / 02683940610690169$

Sarti, D. (2014). Job resources as antecedents of engagement at work: Evidence from a long-term care setting. Human Resource Development Quarterly, 25, 213-237. http://doi-org.libaccess.sjlibrary.org/10.1002/hrdq.21189 
Schaufeli, W. B., \& Bakker, A. B. (2004). Job demands, job resources, and their relationship with burnout and engagement: A multi-sample study. Journal of Organizational Behavior, 25, 293-315. http://doi-org.libaccess.sjlibrary.org/ 10.1002/job.248

Schaufeli, W. B., Salanova, M., González-Romá, V., \& Bakker, A. B. (2002). The measurement of engagement and burnout: A two sample confirmatory factor analytic approach. Journal of Happiness Studies: An Interdisciplinary Forum on Subjective Well-Being, 3, 71-92. http://doi-org.libaccess.sjlibrary.org/10.1023/ A:1015630930326

Shuck, B., Twyford, D., Reio, T. G., Jr., \& Shuck, A. (2014). Human resource development practices and employee engagement: Examining the connection with employee turnover intentions. Human Resource Development Quarterly, 25, 239-270. http://doi-org.libaccess.sjlibrary.org/10.1002/hrdq.21190

Staw, B. (1980). The consequences of turnover. Journal of Occupational Behaviour, 1, 253-273. Retrieved from www.jstor.org/stable/3000143

Stinglhamber, F., \& Vandenberghe, C. (2003). Organizations and supervisors as sources of support and targets of commitment: A longitudinal study. Journal of Organizational Behavior, 24, 251-270. http://doi-org.libaccess.sjlibrary.org/ 10.1002/job.192

Tett, R. P., \& Meyer, J. P. (1993). Job satisfaction, organizational commitment, turnover intention, and turnover: Path analyses based on meta-analytic findings. Personnel Psychology, 46, 259-293. http://doi-org.libaccess.sjlibrary.org/10.1111/j.17446570.1993.tb00874.x

Tziner, A., \& Birati, A. (1996). Assessing employee turnover costs: A revised approach. Human Resource Management Review, 6, 113-122. http://doiorg.libaccess.sjlibrary.org/10.1016/S1053-4822(96)90015-7

Ware, B. L. (2012). Integral Talent Systems Employee Engagement Survey Manager Tool Kit (Eds.).

Weiss, H.M. (2002) Deconstructing job satisfaction: Separating evaluations, beliefs and affective experiences. Human Resource Management Review, 12, 173-194. http://dx.doi.org/10.1016/S1053-4822(02)00045-1

Yalabik, Z. Y., Popaitoon, P., Chowne, J. A., \& Rayton, B. A. (2013). Work engagement as a mediator between employee attitudes and outcomes. The International Journal of Human Resource Management, 24, 2799-2823. http://doiorg.libaccess.sjlibrary.org/10.1080/09585192.2013.763844 


\section{Appendix}

Demographic Questionnaire

Gender

- Male

- Female

Age

- Under 30

- 30 to 44 years

- 45 to 54 years

- 55 and over

Ethnicity

- American Indian/Alaskan Native

- Asian

- Black or African American

- Hispanic or Latino

- Native Hawaiian or other Pacific Islander

- Two or more races

- White

- Not specified

\section{Tenure}

- Less than 90 days

- 90 days to 1 year

- 1 to 3 years

- 3 to 5 years

- 5 to 10 years

- 10 years and over 
Scale Items

\section{Perceived Supervisor Support Items}

My manager fosters genuine and trusting relationships on the team.

My manager promotes an environment where I feel free to express my opinion.

My manager supports my professional growth and development.

My manager selects competent people for our team.

My manager is approachable.

My manager is aware of my career goals.

My manager provides me with regular feedback to help me improve my performance.

My manager gathers my input when making decisions that affect me.

My manager recognizes me in a manner that I personally value.

My manager treats me with respect.

\section{Work Engagement Items}

On most days, I feel energized when I am at work.

The type of work that I do leverages my personal strengths.

I feel valued and appreciated.

My organization has a culture where I can learn new skills and grow.

My organization provides me with the tools I need to help me advance my career.

I feel motivated to "go the extra mile".

I enjoy the work that I do.

I feel driven to do what it takes to help my organization succeed.

I have the resources I need to do an effective job.

I am proud to work for my organization.

My organization has a culture of recognition for good performance.

I am growing personally and professionally at work.

\section{Turnover Intention Item}

The chances of leaving my job voluntarily during the next year are: 